\title{
Using the Market to Address Climate Change: Insights from Theory \& Experience
}

\section{Citation}

Aldy, Joseph, and Robert N. Stavins. "Using the Market to Address Climate Change: Insights from Theory \& Experience." Deadalus 141.2 (Spring 2012): 45-60.

\section{Published Version}

http://dx.doi.org/10.1162/DAED_a_00145

\section{Permanent link}

http://nrs.harvard.edu/urn-3:HUL.InstRepos:10605425

\section{Terms of Use}

This article was downloaded from Harvard University's DASH repository, and is made available under the terms and conditions applicable to Other Posted Material, as set forth at http:// nrs.harvard.edu/urn-3:HUL.InstRepos:dash.current.terms-of-use\#LAA

\section{Share Your Story}

The Harvard community has made this article openly available.

Please share how this access benefits you. Submit a story.

\section{Accessibility}




\title{
Using the Market to Address Climate Change: Insights from Theory \& Experience
}

\author{
Joseph E. Aldy \& Robert N. Stavins
}

Abstract: Emissions of greenhouse gases linked with global climate change are affected by diverse aspects of economic activity, including individual consumption, business investment, and government spending. An effective climate policy will have to modify the decision calculus for these activities in the direction of more efficient generation and use of energy, lower carbon-intensity of energy, and a more carbon-lean economy. The only technically feasible and cost-effective approach to achieving this goal on a meaningful scale is carbon pricing: that is, market-based climate policies that place a shadow-price on carbon dioxide emissions. We examine alternative designs of three such instruments: carbon taxes, cap and trade, and clean energy standards. We note that the U.S. political response to possible market-based approaches to climate policy has been, and will continue to be, largely a function of issues and structural factors that transcend the scope of environmental and climate policy.

JOSEPH E. ALDY is an Assistant Professor of Public Policy at the Harvard Kennedy School.

ROBERT N. STAVINS is the Albert Pratt Professor of Business and Government at the Harvard Kennedy School.

("See endnotes for complete contributor biographies.)

\begin{abstract}
$\mathrm{V}_{\mathrm{i}}$ ual consumption, business investment, and government spending - affect greenhouse gas emissions and, hence, the global climate. An effective climate change policy would change the decision calculus for these activities to promote more efficient generation and use of energy, lower carbon-intensity of energy, and a more carbon-lean economy. There are three ways to accomplish this goal: (1) mandate that businesses and individuals change their technology and emissions performance; (2) subsidize business and individual investment in and use of lower-emitting goods and services; or (3) price the greenhouse gas externality commensurate with the harm that such emissions impose on society.

Externality pricing can promote cost-effective abatement, deliver efficient innovation incentives, avoid picking technology winners, and ameliorate, not exacerbate, government fiscal conditions. When all businesses and households face a common price
\end{abstract}

(C) 2012 by the American Academy of Arts \& Sciences 
Using the per unit of greenhouse gases embodied in Market to fuels, goods, and services, no additional
Address Address policies can lower the total cost of achievChange ing a specified climate policy goal. By pricing carbon pollution, the government defers to private firms and individuals to find and exploit the lowest-cost ways to reduce emissions and to invest in the development of new technologies, processes, and ideas that could mitigate future emissions. A variety of policy approaches fall within the concept of externality pricing, including carbon taxes, cap and trade, and clean energy standards.

In contrast, the conventional approach to environmental policy employs uniform mandates to protect environmental quality. Although uniform technology and performance standards have been effective in achieving some established environmental goals and standards, they tend to lead to non-cost-effective outcomes in which some firms use unduly expensive means to control pollution. In addition, conventional technology or performance standards do not provide dynamic incentives for the development, adoption, and diffusion of environmentally and economically superior control technologies. Once a firm satisfies a performance standard, it has little incentive to develop or adopt cleaner technology. Indeed, regulated firms may fear that if they adopt a superior technology, the government may tighten the standard.

Given the ubiquitous nature of greenhouse gas emissions from diverse sources, it is virtually inconceivable that a standards-based approach could form the centerpiece of a meaningful climate policy. The substantially higher cost of a standards-based policy may undermine support for such an approach, and securing political support may require weakening standards and lowering environmental benefits.

Government support for lower-emitting technologies often takes the form of in- vestment or performance subsidies. Providing subsidies for targeting climatefriendly technologies entails revenues raised by taxing other economic activities (either contemporaneously or in the future, with contemporaneous financing via deficit spending). Given the tight fiscal environment throughout the developed world, it is difficult to justify increasing (or even continuing) the subsidies that would be necessary to change significantly the emissions intensity of economic activity.

Furthermore, by lowering the cost of energy, climate-oriented technology subsidies likely result in socially excessive levels of energy supply and consumption. Thus, subsidies can undermine incentives for efficiency and conservation and impose higher costs per ton abated than cost-effective policy alternatives. In practice, subsidies are typically designed to be technology specific. By designating technology winners, such an approach yields a special-interest constituency focused on maintaining subsidies beyond what may be socially desirable. It also provides little incentive for the development of novel, game-changing technologies.

In contrast, real-world experience demonstrates the power of markets to drive changes in the investment and use of emission-intensive technologies. The runup in gasoline prices in 2008 increased consumer demand for more fuel-efficient new cars and trucks, while also reducing vehicle miles traveled by the existing fleet. ${ }^{1}$ Likewise, electric utilities responded to the dramatic decline in natural gas prices (and decline in the relative gas-coal price) in 2009 and 2010 by dispatching more electricity from gas plants, resulting in lower carbon dioxide $\left(\mathrm{CO}_{2}\right)$ emissions and the lowest share of U.S. power generation by coal in some four decades. ${ }^{2}$ Longer-term evaluations of the impacts of energy prices on markets have found that higher prices have induced more 
innovation - measured by frequency and importance of patents - and increased the commercial availability of more energy-efficient products, especially among energy-intensive goods such as air conditioners and water heaters. 3

Real-world experience with policies that price externalities illustrates the effectiveness of market-based instruments. So-called congestion charges in London, Singapore, and Stockholm have reduced traffic congestion in busy urban centers, lowered air pollution, and delivered net social benefits. The British Columbia carbon tax has reduced carbon dioxide emissions since 2008. The U.S. sulfur dioxide $\left(\mathrm{SO}_{2}\right)$ cap-and-trade program has cut $\mathrm{SO}_{2}$ emissions from U.S. power plants by more than 50 percent since 1990 , resulting in compliance costs one-half of what they would have been under conventional regulatory mandates. ${ }^{4}$ The success of the $\mathrm{SO}_{2}$ allowance trading program motivated the design and implementation of the European Union's Emissions Trading Scheme (EU ETS), the world's largest capand-trade program, focused on cutting $\mathrm{CO}_{2}$ emissions from power plants and large manufacturing facilities throughout Europe. 5 The 198 os phasedown of lead in gasoline, which reduced the lead content per gallon of fuel, served as an early, effective example of a tradable performance standard. ${ }^{6}$ These positive experiences provide motivation to consider market-based instruments - carbon taxes, cap and trade, and clean energy standards - as potential approaches to mitigating greenhouse gas emissions.

I In principle, government imposition of a carbon tax represents the simplest way to price greenhouse gas emissions. ${ }^{7}$ The government could set a tax in terms of dollars per ton of $\mathrm{CO}_{2}$-equivalent on greenhouse gas emissions from all sources covered by the tax. To be cost effective, such a tax would cover all sources, and to Joseph E. be efficient, the carbon price would be set Aldy \& equal to the marginal benefits of emis- Robert $N$. sion reduction: that is, the social cost of carbon. ${ }^{8}$ An efficient carbon tax would be expected to increase over time to reflect the fact that as more greenhouse gas emissions accumulate in the atmosphere, the incremental damage from an additional ton of $\mathrm{CO}_{2}$ becomes greater; such a tax would also include a risk premium to reduce uncertain future damages. ${ }^{9}$ Imposing a carbon tax would provide certainty about the marginal cost of compliance, thereby reducing uncertainty about returns to investment decisions, but would leave economy-wide emissions uncertain.

The government could apply the carbon tax "upstream" on fossil fuel suppliers based on the carbon content of fuels or "downstream" on final emitters at the point of combustion, or it could employ a hybrid of the two. In an upstream approach, refineries and importers would pay a tax based on the carbon content of their gasoline, diesel fuel, or heating oil; coal mine operators would pay a tax reflecting the carbon content of extracted coal; and natural gas companies would pay a tax reflecting the carbon content of their gas production and imports. Focusing on the carbon content of fuels would cover about 98 percent of U.S. $\mathrm{CO}_{2}$ emissions through a relatively small number of firms - two to three thousand - as opposed to the hundreds of millions of smokestacks and tailpipes, for example, that emit $\mathrm{CO}_{2}$ after fossil fuel combustion. Such a tax approach could also cover other greenhouse gases.

A carbon tax would be administratively simple and straightforward to implement. The tax could incorporate existing methods for fuel-supply monitoring and reporting to the regulatory authority. Given the molecular properties of fossil fuels, monitoring their physical quantities yields a 
Using the precise estimate of the emissions they reMarket to lease during combustion. Because an emisAddress sion tax would be similar in form to taxes Change that many fuel suppliers already pay, ${ }^{10}$ firms could easily understand and account for it in their operations.

A crediting system for downstream sequestration could complement the emission tax system. A firm that captures and stores $\mathrm{CO}_{2}$ through geological sequestration, thereby preventing the gas from entering the atmosphere, could generate $\mathrm{CO}_{2}$ tax credits. Similar approaches could be undertaken to promote biological sequestration in forestry and agriculture and, potentially, emission-reduction projects ("offsets") in other countries.

Faced with an emission tax, fuel suppliers will increase the cost of the fuels they sell. This will effectively pass down the tax through the energy system, creating incentives for fuel-switching and investments in more energy-efficient technologies. The impact of a carbon tax on emission mitigation and the economy will depend in part on the amount and use of the tax revenue. An economy-wide U.S. carbon tax of $\$ 2 \mathrm{O}$ per ton of $\mathrm{CO}_{2}$ would likely raise more than $\$ 100$ billion per year. The revenue could allow for reductions in existing distortionary taxes on labor and capital, thereby stimulating economic activity and offsetting some of the policy's costs. For example, reducing the payroll tax by 2 percentage points in 2012 could be financed with an economy-wide carbon tax on the order of $\$ 15$ to $\$ 20$ per ton of $\mathrm{CO}_{2}$. Other socially valuable uses of revenue include reducing the federal deficit, funding energy R\&D, and compensating low-income households for the burden of higher energy prices.

The implementation of a carbon tax (or cap-and-trade system) will increase the cost of consuming energy and could adversely affect the competitiveness of energy-intensive industries. This competi- tiveness effect can result in negative economic and environmental outcomes: firms may relocate facilities to countries without meaningful climate change policies, thereby increasing emissions in these new locations and offsetting some of the environmental benefits of the policy. Because a majority of developed countries' emissions occur in non-traded sectors - that is, electricity, transportation, and residential buildings - this so-called emission leakage may, in fact, be relatively modest. However, energy-intensive manufacturing industries that produce goods competing in international markets may face incentives to relocate.

Additional emission leakage may occur through international energy markets. As countries with climate policies reduce their consumption of fossil fuels and drive down fuel prices, those countries without emission mitigation policies may be induced to increase their consumption. The fact that leakage undermines the environmental effectiveness of any unilateral effort to mitigate emissions makes international cooperation and coordination all the more important.
A cap-and-trade system constrains the aggregate emissions of regulated sources by creating a limited number of tradable emission allowances - in sum equal to the overall cap - and requiring those sources to surrender allowances to cover their emis- sions. ${ }^{11}$ Faced with the choice of surren- dering an allowance or reducing emis- sions, firms place a value on the allow- ance reflecting the cost of the emission reductions that can be avoided by surren- dering the allowance. Regardless of the initial allowance distribution, trading can lead allowances to be put toward their highest-valued use: covering those emis- sions that are the most costly to reduce and providing the incentive to undertake the least costly reductions. 
In developing a cap-and-trade system, policy-makers must decide on several elements of the system's design. First, they must determine how many allowances to issue (that is, the level of the emission cap) and the scope of the cap's coverage, identifying the types of greenhouse gas emissions and sources covered as well as deciding whether to regulate upstream (based on carbon content of fuels) or downstream (based on monitored emissions). Policy-makers must then determine whether to freely distribute or auction allowances. Free allowance allocation could be "grandfathered," reflecting some historical record such as recent fossil fuel sales. Grandfathering involves a transfer of wealth, equal to the value of the allowances, to existing firms, whereas an auction transfers the same level of wealth to the government. In theory, the government would collect revenue identical to that from a tax producing the same amount of emission abatement. As with tax receipts, auction revenues could be used to reduce distortionary taxes or finance other programs.

In an emission-trading program, cost uncertainty - unexpectedly high or volatile allowance prices - can undermine political support for climate policy and discourage investment in new technologies and R\&D. Therefore, attention has turned to incorporating the "cost containment" measures of offsets, allowance banking and borrowing, safety valves, and price collars in cap-and-trade systems.

An offset provision allows regulated entities to offset some of their emissions with credits from emission-reduction measures outside the cap-and-trade system's scope of coverage. Allowance banking and borrowing effectively permits emission trading across time. The flexibility to save an allowance for future use (banking) or to bring a future period allowance forward for current use (bor- rowing) promotes cost-effective abate- Joseph E. ment and redefines a series of annual emission caps as a cap on cumulative emisAldy \& Robert N. Stavins sions over a period of years.

A safety valve puts an upper bound on the costs that firms will incur to meet an emission cap by offering the option of purchasing additional allowances at a predetermined price. This effective price ceiling reflects a hybrid approach: a capand-trade system that transitions to a tax in the presence of unexpectedly high mitigation costs. When firms exercise a safety valve, their aggregate emissions exceed the emission cap. A price collar combines the ceiling of a safety valve with a price floor created, for example, by a reserve price in allowance auctions.

Increasing certainty about mitigation cost reduces certainty about the quantity of emissions. Smoothing allowance prices over time through banking and borrowing reduces emission certainty in any given year but maintains certainty of aggregate emissions over a longer time period. A cost-effective policy with a mechanism insuring against unexpectedly high costs increases the likelihood that firms will comply with their obligations and can facilitate a country's participation and compliance in a global climate agreement.

As with a carbon tax, cap-and-trade programs could include some variant of a border tax to mitigate the competitiveness impacts of domestic climate policy and encourage trade partners to take on comparable mitigation policies. Border measures under a carbon tax or cap and trade raise policy questions about the application of a trade "stick" to encourage broader and more extensive emission mitigation actions globally, as well as questions about their legality under the World Trade Organization. ${ }^{12}$

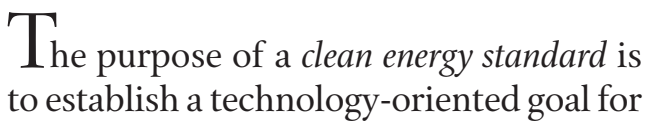


Using the the electricity sector that can be impleMarket to mented cost effectively. ${ }^{13}$ Under such stanAddress dards, power plants generating power with Change technologies that satisfy the standard create tradable credits that they can sell to power plants that fail to meet the standard, thereby minimizing the costs of meeting the standard's goal in a manner analogous to cap and trade. An important distinction is that cap and trade establishes the policy goal in terms of the externality (greenhouse gas emissions), while clean energy standards establish the policy goal in terms of a set of technologies with zeroor low-emission characteristics.

For example, state renewable electricity standards, a restricted type of a clean energy standard, typically identify the objective of the standard as a specific renewable share of total power generation (that increases over time). ${ }^{14} \mathrm{~A}$ few states have implemented alternative energy standards that target renewables, new nuclear capacity, and advanced fossil fuel technologies. Proposals for national standards have targeted a combination of all generating technologies except conventional coal. ${ }^{15}$

Clean energy standards that focus on technology targets do not explicitly price the greenhouse gas externality and thus impose a higher cost for a given amount of emission reductions than a carbon tax or cap-and-trade program. A renewable mandate treats coal-fired power, gasfired power, and nuclear power as equivalent-none of these technologies create credits necessary for compliance-and therefore provides no incentive to switch from emission-intensive coal to emissionlean gas or emission-free nuclear.

A more cost-effective approach to a clean energy standard would employ a technology-neutral performance standard, such as tons of $\mathrm{CO}_{2}$ per megawatt hour of generation ( $\left.\mathrm{tCO}_{2} / \mathrm{MWh}\right)$. Given that all power sources, from fossil fuels to renewables, could be eligible under such a performance standard, this approach would provide better innovation incentives than a renewable portfolio approach and would enable all possible ways of reducing the emission intensity of power generation. The Canadian province of Alberta has employed a tradable carbon performance standard for most large sources of $\mathrm{CO}_{2}$ emissions, requiring a 12 percent improvement in these sources' emission intensity since 2007.

Power plants would be awarded credits for generating cleaner (less emissionintensive) electricity than the standard, and they could sell these credits to other power plants or save them for future use. Tradable credits promote cost-effectiveness by encouraging the greatest deployment of clean energy from those plants that can lower their emission intensity at lowest cost. Clean power plants could then sell their extra credits to other plants that face higher costs for deploying clean energy. The creation and sale of clean energy credits would provide a revenue stream that could conceivably enable the financing of low- and zero-emission power plant projects.

Eligible technologies for the standard could extend beyond generation technologies, permitting improvements in energy efficiency and emission-offset activities to create tradable credits. Extending the carbon price to a broader set of activities could improve cost-effectiveness, but there are risks in allowing for energy efficiency and other offsets. In both cases, estimating the offset is complex, requires extensive review and monitoring by regulators, and risks undermining the objective of a clean energy standard if some projects do not, in practice, deliver meaningful emission reductions.

Monitoring and enforcement would be relatively straightforward, given that regulators already track electricity generation 
and $\mathrm{CO}_{2}$ emissions at U.S. power plants. A power plant could demonstrate compliance through a combination of the following approaches: (1) the plant has lesser or equal emissions per megawatt hour than the standard (or a share of power from clean energy exceeding the standard); (2) the plant purchases clean energy credits from other power plants; or (3) the plant purchases additional clean energy credits from the federal government at a preset price. The last option is similar to "alternative compliance payments" in state electricity portfolio standards (and akin to the hybrid safety-valve approach under a cap-and-trade program) that finance some state energy R\&D programs. This approach could provide more certainty about compliance cost under a clean energy standard.

A clean energy standard represents a de facto free allocation of the right to emit greenhouse gases. Suppose that the federal government created a clean energy performance standard of $0.5 \mathrm{tCO}_{2} / \mathrm{MWh}$ (in 2010, U.S. power sector emission intensity was $0.56 \mathrm{tCO}_{2} / \mathrm{MWh}$ ). Every power plant implicitly receives the right to emit a half-ton of $\mathrm{CO}_{2}$ per megawatt hour of generation under such a standard, similar to an output-based allocation of emission allowances under cap and trade.

M arket-based policies can support cost-effective attainment of policy goals. A carbon tax and cap and trade establish a common price for emitting a ton of $\mathrm{CO}_{2}$, and the private sector has the flexibility to identify and exploit the least costly ways of reducing emissions. This approach is vastly superior to command-and-control regulatory mandates and can result in lower costs per ton of $\mathrm{CO}_{2}$ abated than a clean energy standard. Even a clean energy standard designed as a tradable carbon performance standard would be less cost effective than cap and trade or a tax be- cause it does not provide a comparable Joseph E. incentive for efficiency and conservation. Aldy \& The implicit free allocation of the right to Robert $N$. emit is functionally an output-based subsidy that will result in more electricity generated and consumed than under cap and trade or a tax.

A renewable electricity standard is even less cost effective because it proscribes some low- and zero-emission technologies from the set of compliance options. In theory, this type of standard could mandate so much renewable power that it spurs a socially excessive amount of total generating capacity, lowers the price of electricity (at least in the short run), and causes a net increase in electricity consumption, contrary to the efficiency and conservation incentives under cost-effective approaches.

C Cost-effective implementation is necessary but not sufficient for a climate policy to maximize net social benefits. A socially efficient policy, one resulting in marginal costs equal to marginal benefits of emission reduction, would require setting the carbon price equal to the estimated social cost of carbon. Alternatively, policy-makers could set an emission cap that would deliver an expected allowance price equal to the estimated social cost of carbon. Under a clean energy standard, the stringency of the performance standard could be set to yield expected credit prices on par with the social cost of carbon, although the weaker incentive for efficiency and conservation would result in some efficiency losses.

A market-based policy may raise revenue to finance reductions in taxes that discourage the supply of labor and capital. Lowering payroll, income, or capital gains tax rates could offset some of the costs of a climate policy. A well-designed marketbased policy with a modest carbon price and efficiently targeted reduction in tax 
Using the rates could -in principle-cause a net Market to increase in GDP, although - in practice Address the more likely outcome is some savings Change in the policy's cost. ${ }^{16}$ In general, recycling revenue back into the economy by lowering existing distortionary taxes can allow for a more aggressive greenhouse gas mitigation policy that maximizes net social benefits.

$\mathrm{I}_{\mathrm{r}}$ tax and a cap-and-trade program could be designed and implemented to yield an identical carbon price and emission reductions. But the choice of policy instrument can affect the net social benefits, given the real-world uncertainty that characterizes emission mitigation. ${ }^{17}$ The government must implement a climate policy before uncertainty about the cost of emission mitigation can be resolved. If mitigation costs are higher than the government expected, then the climate policy will yield either (a) fewer emission reductions if the government implemented a carbon tax; or (b) higher costs if the government implemented cap and trade. If the foregone economic benefits from fewer emission reductions under the tax are less than the higher costs under the cap-and-trade program, then a tax would be the preferred policy instrument under uncertainty. Otherwise, cap and trade would likely maximize net social benefits relative to a carbon tax.

Uncertainty about the price of carbon inhibits private-sector investment. In recent years, uncertainty about the type, design, and stringency of climate policy has adversely affected new energy and climaterelated technology investment. Uncertainty about future modifications to a climate policy may also deter investment, especially for long-lived energy-related capital. For example, a future government could relax policy stringency (with a lower carbon tax or higher emission cap) that would lower the economic return to low- and zero-carbon technology investments. Alternatively, under a cap-andtrade regime, a future government could wipe out the value of an emission allowance bank (the allowances set aside and banked for future use), increasing the stringency of the cap-and-trade program, not unlike recent experience with the effect of regulatory changes on the U.S. $\mathrm{SO}_{2}$ cap-and-trade program.

While the business community would prefer cost certainty, the environmental community favors certainty over greenhouse gas emission levels. Placing much greater weight on emission reductions reflects the concern of some in the environmental community that business will simply "buy its way out" under a carbon tax and fail to undertake emission mitigation, even though it may be in businesses' interests to do so.

Real-world experience has addressed uncertainty by pursuing hybrid pricequantity approaches, such as state renewable electricity standards that establish quantity renewable goals and include alternative compliance payments that serve as a price ceiling on tradable renewable credits. Such hybrid approaches can provide insurance against policy costs reaching unexpected heights. They may also represent a way of imposing an implicit carbon tax if a cap-and-trade program's safety valve is set at a level that has a very high probability of being triggered. Although public policies are frequently
proposed and analyzed in isolation, they
in fact interact with one another in a num-
ber of important ways, which can affect a
policy's environmental effectiveness and
costs. Policies of all kinds - both market-
based instruments and conventional pol-
icies - act as implicit taxes and interact
with preexisting taxes in ways that drive
up the policies' costs - the so-called tax- 
interaction effect. ${ }^{18}$ Those policy instruments that produce revenues for government, including carbon taxes and cap and trade with auctioned allowances, can dedicate part or all of their revenue to cutting existing, distortionary taxes, thereby offsetting some or (in principle) all of the tax-interaction effect. These interactions can have profound effects on the costs of a climate policy. ${ }^{19}$

The interaction of flexible, quantitybased policies, such as cap-and-trade systems and tradable clean energy standards, with other climate policies introduces an additional set of issues. In general, allowed trading means that once a flexible, averaging type of policy instrument is in place, any attempt to elicit greater reductions from some specific source or sector under the cap will essentially be undone by some other source or sector covered under the cap. Moreover, when marginal abatement costs at the specific source or sector are increased, the overall flexible (cap and trade) regime is no longer cost effective. This is a major issue for cap-and-trade systems, renewable electricity standards, clean energy standards, and motor-vehicle fuel efficiency standards. Problematic interactions can occur when one policy instrument is nested within another, as with subnational and national policies, ${ }^{20}$ or when two policy instruments coexist within the same political jurisdiction. ${ }^{21}$ The effects are potentially less severe with a carbon tax than with quantity-based policies because the multiple policies could yield a lower emission level than the carbon tax in isolation, but that benefit would come at the expense of cost effectiveness.

G to mitigate it play out in the global commons, it is important that any U.S. policy actions be carefully coordinated with the actions or anticipated actions of other countries. Otherwise, U.S. policies may Joseph E. have no more than trivial environmental Aldy \& impacts (despite their cost) and can in- Robert $N$. crease other countries' emissions through induced leakage of carbon-intensive economic activity.

Cap-and-trade systems seem to have emerged as the preferred national and regional instrument for reducing greenhouse gas emissions throughout much of the industrialized world. The Clean Development Mechanism (CDM), an international emission-reduction credit system, has developed a substantial constituency despite concerns about its performance. Because linkage between tradable permit systems (that is, unilateral or bilateral recognition of allowances from one system for use in another) can reduce compliance costs and improve market liquidity, there is great interest in linking cap-and-trade systems with each other, as well as to the CDM and other credit systems. There are not only benefits but also concerns associated with various types of linkages, ${ }^{22}$ but it is safe to say that such linkage may play one of three possible roles: as an independent bottomup international climate policy architecture; as a step in the evolution of a topdown architecture; or as an ongoing element of a larger climate policy agreement.

A parallel issue arises with respect to national or subnational carbon taxes: namely, they can be linked in productive ways. For purposes of overall cost effectiveness, the various taxes would need to be set at the same level, that is, harmonized. ${ }^{23}$ The prospect of harmonization is complicated by equity issues - would developing countries harmonize taxes without some form of side payments? and related tax issues: how might carbon tax harmonization account for preexisting energy subsidies in developing countries and high preexisting energy taxes in some developed countries? 
Using the

Market to

Address

Climate

Change
Considering the variety of policy instruments - both market-based and conventional command-and-control - that countries can employ to reduce their greenhouse gas emissions, it is important to ask whether a diverse set of heterogeneous national, subnational, or regional climate policy instruments can be linked in productive ways. The simple answer is that such a set of instruments can be linked, although coordinating a set of more homogeneous tradable permit systems would be easier. ${ }^{24}$ The basic approach behind emission-reduction credit systems such as the CDM can be extended to foster linkage opportunities among diverse policy instruments, including cap and trade, taxes, and certain regulatory systems. ${ }^{25}$

Countries could coordinate effectively through the unilateral use of border adjustments. A national carbon tax, for instance, would take the form of a tax on imports equivalent to the implicit tax on the same goods produced domestically. In the cap-and-trade climate legislation passed by the U.S. House of Representatives in 2009, border adjustments covered only a limited set of energy-intensive, trade-exposed manufactured bulk products.

Po feasibility. In general, it may be necessary to elicit support from concentrated interests. ${ }^{26}$ A key question is whether the process of developing such support reduces a policy's effectiveness (for example, by muting the price signals of a marketbased instrument) or increases its cost. Such outcomes are frequently the case. However, a key merit of one of the policy instruments we have considered - namely, cap and trade - is that under many circumstances, the process of developing political support need not impair the policy. An important property of such systems - the independence of the equilibri- um allocation of allowances after trading from the initial allocation ${ }^{27}$ - permits the legislature to distribute allowances in a way that builds a constituency of political support for enactment without jeopardizing the policy's environmental integrity or its cost effectiveness. ${ }^{28}$

At the same time, it is important to recognize that those market-based policy instruments that raise revenues for government - including taxes and auctioned allowances - can have their own political attraction, particularly at a time of chronic government budgetary deficits.

Any public policy, whether cost effective or not, will inevitably have significant distributional consequences, even if it does no more than reinforce the status quo. In the case of U.S. climate change policy, the near-term distributional impacts will primarily reflect the cost of mitigating emissions. The climate benefits to any single nation from its emission-reduction efforts will be spread globally and over several generations. Any meaningful climate policy will increase energy prices, particularly with regard to energy derived from coal combustion and, to a lesser extent, petroleum and natural gas combustion. Mitigation policies would also benefit firms (and some regions) with zero-carbon technologies, such as wind, solar, and energy efficiency technologies. The economic incidence of energy price increases will make up a considerable share of the distributional impacts, which will vary across sectors of the economy, across regions, and across income groups. These impacts are also likely to have profound political impacts on the feasibility of climate policy and the choice among climate policy instruments.

The political-economy implications of the costs associated with various policy instruments give public officials strong incentive to identify and select policies 
and instruments with minimal perceived costs. In some cases, policies and/or policy instruments may indeed be low-cost, either because they are essentially unambitious or because they are cost effective.

Another option is for public officials to identify policy instruments that hide or partially obscure their costs. Largely for this reason, ordinary performance and technology standards have long been favored over market-based instruments. ${ }^{29}$ A prime example is the apparent political attraction of Corporate Average Fuel Economy standards as a means of increasing the fuel efficiency of American automobiles, in contrast with the political aversion to gasoline taxes, even though the latter would accomplish more at lower cost (but in a highly visible manner). ${ }^{30}$

P Public and political interest in a marketbased policy instrument may respond positively to the threat of a high-cost regulatory alternative. The business community may prefer a more cost-effective (and hence potentially lower-cost) market-based policy to traditional commandand-control regulation. Some in the environmental community may also support a cost-effective policy if it enables a more ambitious environmental goal than is possible under a conventional regulatory mandate.

During the policy debate over the 1990 Clean Air Act amendments, the prospect of a costly regulatory standard for power plant $\mathrm{SO}_{2}$ emissions prompted interest in a cap-and-trade regime that became the centerpiece of the law's approach to combat acid rain. Building on the successful experience with $\mathrm{SO}_{2}$ cap and trade, the Environmental Protection Agency (EPA) worked with Northeastern, Mid-Atlantic, and Midwestern states to design a nitrogen oxide emissions cap-and-trade program to reduce ground-level ozone pollution (smog). While states had the option to implement a conventional command- Joseph E. and-control regulation in lieu of joining Aldy \& the cap-and-trade regime, every state chose Robert $N$. to pursue the more cost-effective trading approach.

The threat of a high-cost regulatory alternative for greenhouse gas emissions could influence potential interest in a market-based policy approach. First, the EPA could design regulations under the existing Clean Air Act that include some form of cap and trade or a variant of a clean energy standard. While existing law would circumscribe some potentially appealing attributes of a market-based climate policy (including revenue generation and cost containment through a safety valve) as well as prohibit a carbon tax outright, it could allow for a more costeffective approach than conventional regulatory mandates. Second, the risk of a politically (and potentially economically) unpalatable regulatory scheme under the Clean Air Act may also mobilize interest in a legislative alternative.

$\mathrm{Pu}$ Ponsuing a legislative option through Congress could involve a variety of legislative committees that would engage a range of special interests. Consider the example of the Senate: a carbon-tax bill would likely start in the Finance Committee; a cap-and-trade bill in the Environment and Public Works (EPW) Committee; and a clean energy standard bill in the Energy and Natural Resources Committee. If a cap-and-trade or clean energy standard bill raises significant revenue, it would likely be referred to the Finance Committee, while any bill that modifies the Clean Air Act (for example, by substituting a market-based policy for existing statutory authority) would likely be referred to the EPW Committee. The committee that begins drafting a bill will shape that bill in line with its priorities: for example, the Finance Committee will 
Using the prioritize raising revenue, while the EPW Market to will lay out ambitious environmental goals. Address The persistence of policy design as a bill Change moves through the legislative process would result in a final law reflecting those initial efforts.

A successful effort in designing and implementing a market-based policy would also benefit from the positive experiences on other policy fronts related to the gradual increase in policy stringency. In 2008, British Columbia implemented a carbon tax starting at $\$ 10$ (Canadian dollars) per ton of carbon dioxide and climbing annually until it reaches $\$ 30 /$ $\mathrm{tCO}_{2}$ in 2012. To complement this gradual implementation of the policy, in the month before tax collection began, the provincial government provided checks to households representing the revenue expected to be raised by the tax in the first year. As the carbon tax revenue has increased, households and businesses have enjoyed larger reductions in their income taxes.

The $\mathrm{SO}_{2}$ cap-and-trade program was phased in over two time periods, with the largest power plants covered by the program starting in 1995 and the balance of the covered facilities entering the program in 2000. The EU ETS began with a pilot phase in 2005 that imposed a relatively lax emission cap to enable time for covered facilities and government regulators to gain experience with the trading regime before moving into a more stringent second phase in 2008. State renewable electricity and alternative energy standards have likewise started with relatively modest goals: the average renewable target for the twenty-four operational state programs in 2010 was about 4.7 percent, but will increase by a factor of three by 2020 .

$\mathrm{T}_{\mathrm{h}}$ market-based approaches to climate policy has been and will continue to be large- ly a function of issues and structural factors that transcend the scope of environmental and climate policy. Because a truly meaningful climate policy - whether market-based or conventional in design will have significant impact on economic activity in a wide variety of sectors (given the pervasiveness of energy use in a modern economy) and in every region of the country, it is not surprising that proposals for such policies bring forth significant opposition, particularly during difficult economic times.

In addition, U.S. political polarization - which began some four decades ago and accelerated during the economic downturn - has decimated what had long been the key political constituency in Congress for environmental (and energy) action: namely, the middle, including both moderate Republicans and moderate Democrats. ${ }^{31}$ Whereas congressional debates about environmental and energy policy have long featured regional politics, they are now fully and simply partisan. In this political maelstrom, the failure of cap-and-trade climate policy in the Senate in 2010 was collateral damage in a much larger political war.

Better economic times may reduce the pace - if not the direction - of political polarization. Furthermore, the ongoing challenge of large federal budgetary deficits may at some point increase the political feasibility of new sources of revenue. When and if this happens, consumption taxes (as opposed to traditional taxes on income and investment) could receive heightened attention; primary among these might be energy taxes, which, depending on their design, can be significant climate policy instruments.

Some would argue that a mobilizing event will soon precipitate U.S. climate policy action. But the nature of the climate change problem itself helps explain much of the relative apathy among the 
U.S. public and suggests that any such mobilizing event may come "too late." Nearly all our major environmental laws have been passed in the wake of highly publicized environmental events or "disasters," including the spontaneous combustion of the Cuyahoga River in Cleveland, Ohio, in 1969, and the discovery of toxic substances at Love Canal in Niagara Falls, New York, in the mid-197os. But note that the day after the Cuyahoga River caught on fire, no article in The Cleveland Plain Dealer commented that the cause was uncertain, that rivers periodically catch on fire from natural causes. On the contrary, it was immediately apparent that the cause was waste dumped into the river by adjacent industries. A direct consequence of the observed "disaster" was, of course, the Clean Water Act of 1972.

Climate change is distinctly different. Unlike the environmental threats addressed successfully in past U.S. legislation, climate change is essentially unobservable. We observe the weather, not the climate. Until there is an obvious and sudden event - such as a loss of part of the Antarctic ice sheet leading to a dramatic sea-level rise-it is unlikely that public opinion in the United States will provide the bottom-up demand for action that has inspired previous congressional action on the environment over the past forty years.

Despite this somewhat bleak assessment of the politics of climate change policy in the United States, it is much too soon to speculate on what the future will hold for the use of market-based policy instruments, whether for climate change or other environmental problems. On the one hand, it is conceivable that two decades (1988-2008) of high receptivity in U.S. politics to cap and trade and offset mechanisms will turn out to be no more than a relatively brief departure from a long-term trend of reliance on conven- tional means of regulation. On the other Joseph E. hand, it is also possible that the recent Aldy \& tarnishing of cap and trade in national Robert $N$. political dialogue will itself turn out to be a temporary departure from a long-term trend of increasing reliance on marketbased environmental policy instruments. Perhaps the ongoing interest in these policy mechanisms in California (Assembly Bill 32), the Northeast (Regional Greenhouse Gas Initiative), Europe, and other countries will form a bridge to a changed political climate in Washington. 
Using the

Market to

Address

Climate

Change
ENDNOTES

* Contributor Biographies: JOSEPH E. ALDY is an Assistant Professor of Public Policy at the Harvard Kennedy School, a Nonresident Fellow of Resources for the Future, and a Faculty Research Fellow of the National Bureau of Economic Research. His research has been published in the Journal of Economic Literature, the Review of Economics and Statistics, and the Journal of Environmental Economics and Management, among others. He is the coeditor of PostKyoto International Climate Policy: Implementing Architectures for Agreement (with Robert Stavins, 2010) and Architectures for Agreement: Addressing Global Climate Change in the Post-Kyoto World (with Robert Stavins, 2007).

ROBERT N. STAVINS is the Albert Pratt Professor of Business and Government at the Harvard Kennedy School, a University Fellow of Resources for the Future, and a Research Associate of the National Bureau of Economic Research. His research has appeared in the American Economic Review, the Journal of Economic Perspectives, and the Quarterly Journal of Economics, among others. His edited books include Economics of the Environment: Selected Readings (6th ed., 2012), Post-Kyoto International Climate Policy: Implementing Architectures for Agreement (with Joseph Aldy, 2010), and Architectures for Agreement: Addressing Global Climate Change in the Post-Kyoto World (with Joseph Aldy, 2007).

${ }^{1}$ Valerie A. Ramey and Daniel J. Vine, "Oil, Automobiles, and the U.S. Economy: How Much Have Things Really Changed?” NBER Working Paper No. 16067 (Cambridge, Mass. : National Bureau of Economic Research, 2010).

${ }^{2}$ Emissions of Greenhouse Gases in the United States 2009 (Washington, D.C.: U.S. Energy Information Administration, 2011).

3 See David Popp, “Induced Innovation and Energy Prices," American Economic Review 92 (1) (2002): 160-180; and Richard G. Newell, Adam B. Jaffe, and Robert N. Stavins, "The Induced Innovation Hypothesis and Energy-Saving Technological Change," Quarterly Journal of Economics 114 (3) (1999): $941-975$.

4 Curtis Carlson, Dallas Burtraw, Maureen Cropper, and Karen Palmer, " $\mathrm{SO}_{2}$ Control by Electric Utilities: What Are the Gains from Trade?"Journal of Political Economy 108 (2000): 1292 1326.

5 A. Denny Ellerman and Barbara K. Buchner, "The European Union Emissions Trading Scheme: Origins, Allocation, and Early Results," Review of Environmental Economics and Policy 1 (1) (Winter 2007): 66-87.

6 Robert N. Stavins, "Experience with Market-Based Environmental Policy Instruments,” in Handbook of Environmental Economics, vol. 1, ed. Karl-Göran Mäler and Jeffrey Vincent (Amsterdam : Elsevier Science, 2003), chap. 9, $355-435$.

7 For an example of a carbon tax proposal, see Gilbert E. Metcalf, “A Proposal for a U.S. Carbon Tax Swap,” The Hamilton Project Discussion Paper 2007-12 (Washington, D.C. : Brookings Institution, 2007).

8 Interagency Working Group on Social Cost of Carbon, “Technical Support Document : Social Cost of Carbon for Regulatory Impact Analysis Under Executive Order 12866," Washington, D.C., 2010.

9 If society is highly risk averse and is facing uncertain future catastrophic risks, then the efficient carbon price might be so high initially that it would actually decline over time as uncertainty is resolved. See Robert Litterman, "Pricing Climate Change Risk Appropriately," Financial Analysts Journal 67 (5) (2011).

10 For example, U.S. petroleum refineries pay an $8 \uparrow$ oil spill liability tax on every barrel of crude oil they refine. A carbon tax could piggyback on this existing tax. The government could collect about $\$ 4.30$ per barrel for every $\$ 10$ per ton of $\mathrm{CO}_{2}$ of carbon tax at refineries. The administrative ease of employing existing tax infrastructure may be more important for the design of developing-country mitigation policies. See Joseph E. Aldy, Eduardo Ley, and Ian 
W.H. Parry, “A Tax-Based Approach to Slowing Global Climate Change,” National Tax Journal Joseph E. $61(2008): 493-517$.

${ }^{11}$ For an example of a cap-and-trade proposal, see Robert N. Stavins, “A U.S. Cap-and-Trade Stavins System to Address Global Climate Change,” The Hamilton Project Discussion Paper 2007-13 (Washington, D.C. : Brookings Institution, 2007).

12 For a discussion of relevant trade policy and legal questions, see Lael Brainard and Isaac Sorking, eds., Climate Change, Trade, and Competitiveness: Is a Collision Inevitable? (Washington, D.C.: Brookings Institution Press, 2009); and Jeffrey Frankel, "Global Environment and Trade Policy," in Post-Kyoto International Climate Policy: Implementing Architectures for Agreement, ed. Joseph E. Aldy and Robert N. Stavins (New York: Cambridge University Press, 2010), 493-529.

13 One proposal for a clean energy standard is discussed in Joseph E. Aldy, "Promoting Clean Energy in the American Power Sector," The Hamilton Project Discussion Paper 2011-04 (Washington, D.C. : Brookings Institution, 2011).

14 See The Effects of Renewable or Clean Electricity Standards (Washington, D.C.: U.S. Congressional Budget Office, July 2011).

15 See American Clean Energy Leadership Act of 2009, S. 1462, 111th Cong., sec. 132; Practical Energy and Climate Plan Act of 2010, S. 3464, 111th Cong., sec. 301; and President Obama's 2011 State of the Union address.

16 Lawrence H. Goulder and Ian W.H. Parry, "Instrument Choice in Environmental Policy," Review of Environmental Economics and Policy 2 (2) (2008): 152- 174.

17 See Martin L. Weitzman, “Prices vs. Quantities,” Review of Economic Studies 41 (1974) : 477 491.

18 See Lawrence H. Goulder, “Environmental Taxation and the 'Double Dividend' : A Reader’s Guide,”International Tax and Public Finance 2 (2) (August 1995).

19 See Goulder and Parry, "Instrument Choice in Environmental Policy."

${ }^{20}$ See Lawrence H. Goulder and Robert N. Stavins, "Challenges from State-Federal Interactions in U.S. Climate Change Policy,” American Economic Review Papers and Proceedings 101 (3) (2011): 253-257; and Meghan McGuinness and A. Denny Ellerman, "The Effects of Interactions between Federal and State Climate Policies,” Working Paper WP-2008-004, Massachusetts Institute of Technology Center for Energy and Environmental Policy Research, 2008.

21 See Carolyn Fischer and Louis Preonas, "Combining Policies for Renewable Energy: Is the Whole Less than the Sum of Its Parts?" International Review of Environmental and Resource Economics 4 (1) (2010): 51-92; Arik Levinson, "Interactions Among Climate Policy Regulations," NBER Working Paper No. 16109 (Cambridge, Mass. : National Bureau of Economic Research, 2010); and Environment Directorate, Organisation for Economic Co-operation and Development, Interactions Between Emission Trading Systems and Other Overlapping Policy Instruments (Paris: OECD, 2011).

22 See Judson Jaffe, Matthew Ranson, and Robert Stavins, "Linking Tradable Permit Systems: A Key Element of Emerging International Climate Policy Architecture," Ecology Law Quarterly 36 (2010): $789-808$.

23 See Richard N. Cooper, “The Case for Charges on Greenhouse Gas Emissions,” in Post-Kyoto International Climate Policy, ed. Aldy and Stavins, 151-178.

24 See Robert W. Hahn and Robert N. Stavins, What Has the Kyoto Protocol Wrought? The Real Architecture of International Tradable Permit Markets (Washington, D.C. : AEI Press, 1999).

25 See Gilbert E. Metcalf and David Weisbach, "Linking Policies When Tastes Differ: Global Climate Policy in a Heterogeneous World," Discussion Paper 2010-38, Harvard Project on International Climate Agreements, Belfer Center for Science and International Affairs, Harvard Kennedy School, July 2010. 
Using the ${ }^{26}$ See Nathaniel Keohane, Richard Revesz, and Robert Stavins, "The Choice of Regulatory InMarket to struments in Environmental Policy," Harvard Environmental Law Review 22 (2) (1998): 313Address 367.

Climate

Change 27 See David W. Montgomery, "Markets in Licenses and Efficient Pollution Control Programs," Journal of Economic Theory 5 (3) (1972): 395 - 418.

28 There are, however, certain circumstances in which this independence axiom fails; see Robert W. Hahn and Robert N. Stavins, "The Effect of Allowance Allocations on Cap-andTrade System Performance,” The Journal of Law and Economics (forthcoming). In some cases, the tax-interaction and revenue-recycling impacts of the choice of free allowance allocation could significantly undermine cost effectiveness; see Lawrence H. Goulder, Ian W.H. Parry, Roberton C. Williams III, and Dallas Burtraw, "The Cost-Effectiveness of Alternative Instruments for Environmental Protection in a Second-Best Setting," Journal of Public Economics 72 (1999): 329-360.

29 See Keohane, Revesz, and Stavins, “The Choice of Regulatory Instruments in Environmental Policy."

30 See Robert Crandall, “Policy Watch : Corporate Average Fuel Economy Standards,” Journal of Economic Perspectives 6 (1992): 171-180; and Mark R. Jacobsen, "Evaluating U.S. Fuel Economy Standards in a Model with Producer and Household Heterogeneity," working paper, Department of Economics, University of California, San Diego, September 2010.

31 See Robert N. Stavins, "Polarized Politics Paralyze Policy," The Environmental Forum 28 (6) (November/December 2011): 16. 